\title{
Sustainable Development Goals and Decent Work for Women Homeworkers: Is Public Policy Important?
}

\author{
Novita Tresiana ${ }^{1,{ }^{*}}$ Noverman Duadji ${ }^{1}$ Shabina Atma Zenitha ${ }^{2}$ \\ ${ }^{1}$ Department of Public Administration, Universitas Lampung, Jl. S. Brodjonegoro No.1, Bandar \\ Lampung, Indonesia \\ ${ }^{2}$ Department of Pharmacy, Universitas Gadjah Mada Yogyakarta. Jl. Bulaksumur, Caturtunggal, Kec. \\ Depok, Kabupaten Sleman, Daerah Istimewa Yogyakarta, Indonesia \\ *Corresponding author. Email: novita.tresiana@fisip.unila.ac.id
}

\begin{abstract}
The issue of the gender-based decent work deficit has relevance to policies, means of achieving fair, inclusive and sustainable development. Connecting decent work with the promotion of decent work through data mapping is believed to bring about positive changes at the public policy level. Data requirements are useful for understanding prevalence and working conditions, help increase the visibility of homeworkers and their contribution to the economy and form the basis of sustainable policy making and development. The research objective of mapping the conditions of self-employed home-based workers as an evidence base of promoting decent work for sustainable homeworkers. Methodology uses social mapping techniques, data collection through surveys, questionnaires. The results of a study conducted on 101 women homeworkers described the condition of women home-based workers who were self-reliant as contributing significantly to the economy of the family, society and the country. However, working in substandard conditions requires the efforts of various stakeholders, especially the government to recognize them as workers and strive towards addressing the decent work deficits faced by homeworkers. In promoting decent work, action must be taken regarding positive change at different levels including at the policy level. As the majority of homeworkers are women, promotion of decent work for homeworkers is an important area of work in improving the welfare of women in Indonesia. Contribution: evidence base and basis in the formulation and development of public policies.
\end{abstract}

Keywords: SDGs, Decent Work, Home Base Workers, Gender, Public Policy

\section{INTRODUCTION}

It matters for the community that development needs to be sustainable. Sustainability, of course, is directed at improving the quality of human life around the world, both current and future generations, without over-exploiting the use of natural resources and the carrying capacity of the earth [1]. The four elements of the objective become parameters that can create sustainable development goals through: Economic growth and equity; Social development; Conservation of natural resources (environmental protection); good governance [2] ; [3]. In the 2030 agenda for continuous development places the human and the earth at the center of attention and gives the international and national community an incentive to work together in addressing formidable challenges to face humanitarian problems, including those in the world of work [2] ; [3]; [4].
The International labor organizations/ILO [3] estimates that more than 600 million new jobs need to be created by 2030 , just to keep pace with the worldwide growth of the working age population of around 40 million per year, including the conditions for an estimated 780 million women and men workers to lift themselves and their families out of poverty. The importance of decent work in achieving sustainable development is highlighted by Goal 8 which aims to "promote inclusive and sustainable economic growth, productive employment opportunities and decent work for all [5].

The study is based on the issue of the genderbased decent work deficit in Indonesia which has relevance to policy as well as a means to achieve fair, inclusive and sustainable development [6]; [7]. In Indonesia, the issue of decent work reproduction 
can be seen in the right to work which is enshrined in several policies such as the national constitution/UUD 1945, in particular Article 27 paragraph (2) and 28 paragraph (1), recognition of the right to work under Law No.11 / 2005 on Ratification. ICESCR, ratification of various ILO conventions, and Manpower Act No. 13/2003 which provides a legal basis for the protection of the majority of elements of decent work [8]; [27]; [28];[29]. The Indonesian Central Bureau of Statistics (BPS) recorded around 118 million workers in 2016, only 50 million workers worked in the formal sector [9]. Studies conducted in Indonesia illustrate the fact that more than half of the total number of workers in Indonesia work in the informal sector, the absence of legal protection for informal workers can still be considered insufficient, weak recognition, invisible and minimal social protection, dominated by women and one of them is concentrated at home. based workers, especially independent workers [10]; [11]. The inadequacy of work as informal work is dominated by groups of women as home-based workers [12].

This study focuses on female-dominated homeworkers. Homeworkers are classified in the home-based work sub-contract (have a relationship with the employer) and conduct business activities at home, which bear all the risks of being an independent operator. They buy their own raw materials, supplies, and equipment, and pay for utilities and transportation costs. They sell their finished goods themselves, mainly to local customers and markets but sometimes to international markets. Most do not employ other people but are carried out by families, mostly women, from generation to generation, with grandmothers, mothers and daughters engaged in home work [13]; [14]. Several studies highlighting homeworkers have been carried out and have existed since the existence of the textile industry in 1928, although their existence has been around for a long time, they are largely invisible and not well understood [15]. For many people, homeworkers as a type of profession to earn income and make an important contribution to the well-being of families and communities and face various challenges in improving living and working conditions [10].

Studies in several Asian countries, including Indonesia, illustrate the inadequacy of the vulnerability of women home-based workers who are self-reliant at high risk of poverty, low income and dominated by women [10]; [16]. Several problems of unfit for work are reflected in various aspects of employment, economic aspects and social aspects. Manpower aspects in the form of no recognition, no improvement in skills, no increase in work status, scattered, not organized; economic aspects include the absence of formal data making it difficult to identify, poor structured, multiple burdens; social aspects involve children or other family members, low education, the family shares the risk of work to health and is not considered the main income or main job [17].

Many studies link the decent work deficit of women homeworkers with social protection [18]; [19]. However, it is still rare to connect decent work with a decent work promotion policy. Connecting decent work with the promotion of decent work through data mapping is believed to bring positive changes, including at the level of public policy [20]; [21]; [22]. The data are very useful for understanding the prevalence and working conditions of women based on homework carried out independently, helping to increase the visibility of homeworkers and the contribution they make to the economy and form the basis of policy making and development [23].

The aim of the research is to map the conditions of self-employed home-based workers as an evidence base to promote decent work for sustainable homeworkers. The decent work deficit caused by the lack of attention of policy makers, is not visible in official statistics and labor laws, lack of information on working conditions, lack of consensus and a common understanding of status. Contradictory important role Their important role in increasing the dynamics of the economy, especially the village, especially in absorbing the overflow of labor. Research recommendations can serve as a basis for evidence, a basis for formulating and developing public policies.

\section{METHOD}

The research area is in the coastal area of South Lampung Regency, in January-April 2020. Social mapping is used as a technique to get a picture of society, especially women whose profession is based on home businesses. The steps taken run systematically. Data and information collected about the community, including profiles and social problems that exist in the community [24]. The data was collected by means of a population / sample survey by means of purposive sampling and consisted of 101 homeworkers in 2 coastal community villages; Way Muli Village and Canti Village, South Lampung Regency. Both are villages dominated by female homeworkers and have become pilot projects for home-based industries from the Ministry of Women's 
Empowerment and Child Protection of the Republic of Indonesia.

Data was collected by distributing questionnaires with trained survey officers. Specifically for survey officers, the research team provided training on key concepts related to this survey, including the definition of homeworkers and the linkage of gender equality. The main instrument used for this research is a questionnaire developed by the Ministry of Women's Empowerment and Child Protection (KPPA RI), which consists of 6 dimensions, namely: 1) the identity of the respondents, 2) the dimensions of home industry identification, 3) the dimensions of business identity, 4) dimensions of employment, 5) dimensions of business diversity, 6) dimensions of constraints and expectations [25]. To get a better understanding of the experiences and perceptions of women as homeworkers, the research team also conducted FGDs. Sampling was carried out by identifying through the submission of several screening questions related to the respondent's occupation to verify their status as home-based workers before starting the interview.

\section{RESULT AND ANALYSIS}

\subsection{General Conditions of The Study Site}

A study conducted in South Lampung Regency, which is an coastal area in the southern tip of Sumatra island which became a gateway entry flow of people, goods and services to other provinces on Sumatra island as well as the province of Lampung in particular.

District with an area of reach $2007.01 \mathrm{~km} 2$ capital is the city of Kalianda [26]. Administratively, the area of South Lampung district has boundaries as follows: 1) to the North it borders with the region of Central Lampung Regency East Lampung; 2) South: bordering the Sunda Strait; 3) West bordering counties Pesawaran; 4) the East bordering the Java Sea. Consisting of 17 (seventeen) districts and furthermore consists of villages and neighborhoods as much as 251 villages (248 villages and 3 wards) and a long coastline. There are 39 villages which are located on the 7 th town the location is near the seafront, which includes coastal areas, including Sub Katibung, Sidomulyo, Kalianda, Sragi, Ketapang, Bakauheni and last Sub Rajabasa which is the locus of study.

\subsection{Mapping Characteristics and Environmental Conditions of Women Home- Based Workers}

\subsubsection{Mapping Characteristics of Home- Based Workers}

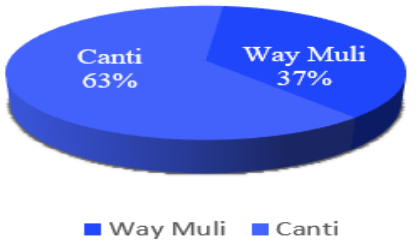

Figure 1. Location Of Women Home-Based Workers

The Village of Canti and the village of Way Muli in the Rajabasa became locus (Figure 2) and the criteria of (a) is locality which figures high poorness, (b) an area that has a lot of home-based businessmen, (c) the area that is a base/bag TKI/TKW (Migrant Worker/Women Migrant Worker), (d) an area that has mal nutrition, Maternal Mortality Rate and Infant Mortality Rate, (d) the area that is minimal gain empowerment activities, (e) is the production center. There are 64 women's home-based worker respondents located in the village of Canti, and 37 in the village of Way Muli, so in the survey managed to identify as many as 101 women, home-based workers.

Figure 3 describes as much as $99 \%$ that became respondents were women and categorized the productive age (15-65). A group of women who become the respondents included in the group that took the group is not productive, that is, a group of children and elderly groups. No illiterate respondents and most have completed secondary school, there are even $3 \%$ of the respondents who have completed a college-level of education. This explains the good quality of human resources of women who become the respondents, they assessed the creative and productive business opportunity can be noticed.

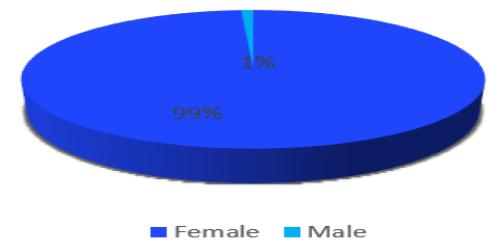

Figure 2. Gender of women home-based Workers 


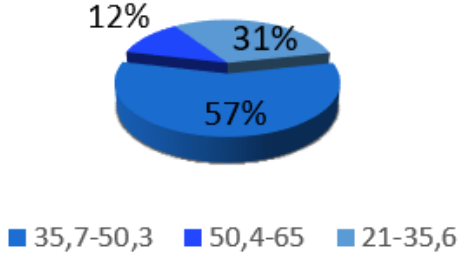

Figure 3. Age of women home-based Workers

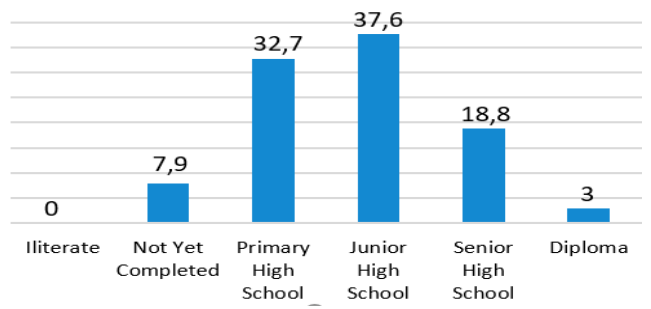

Figure 4. Education of women home-based Workers

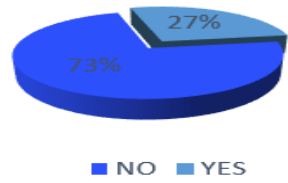

Figure 5. Experience As A Women Migrant Worker (TKW) Women's Home-Based

Figure 5, there are $27 \%$ of respondents have had work experience as TKI/Migrant Labour. His decision to open a home-based business industry is relatively precise. Because in addition to beneficial to the harmony and the resilience of the family economy, can also participate to develop the economic potential of the local community.

\subsubsection{Mapping Business Characteristics and} Environmental Conditions of Work of Women Home-Based Workers

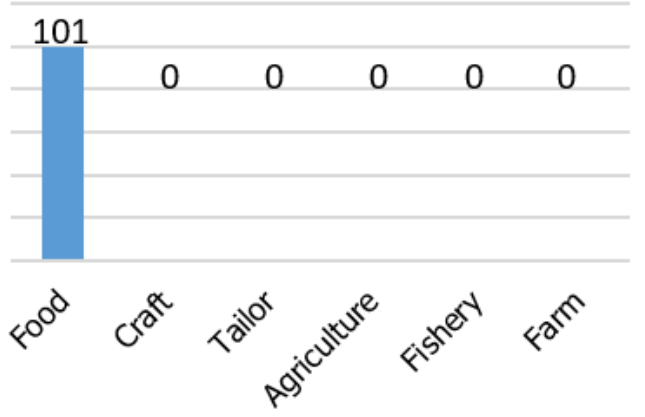

Figure 6. Categories Women's Home-Based Workers

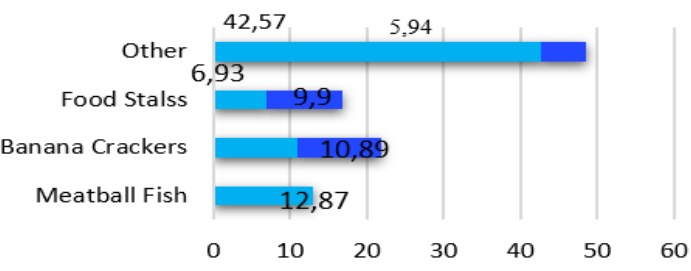

Figure 7. Various Businesses Women's HomeBased Workers

Figure 6 shows a $100 \%$ home-based women workers of businesses that developed in two villages surveyed were in the field of food. The home industry in the areas of food mostly related to the availability of natural resources or raw materials. Types of businesses developed Chips banana and fish meatballs, relatively widely produced, each more than 10 percent of the business unit. Look at the potential area that could be further developed over the availability of raw materials, namely fish and bananas can be done on the development of various of the product. Based on information from the picture, it can also be known when raw fish only, can be generated a wide range of food products, among others: empekempek, nuget, meatballs, and salted fish.

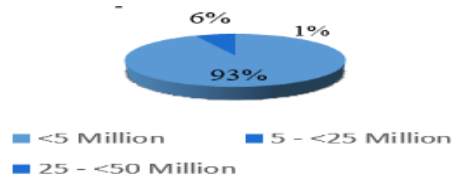

Figure 8. The amount of Initial Capital Women's Home-Based Workers

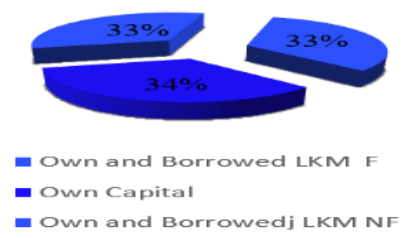

Figure 9. Source of Capital Women's HomeBased Workers

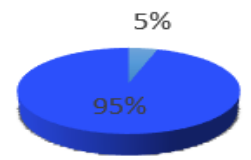

ave permission don't have permission

Figure 10. Business License Women's HomeBased Workers 


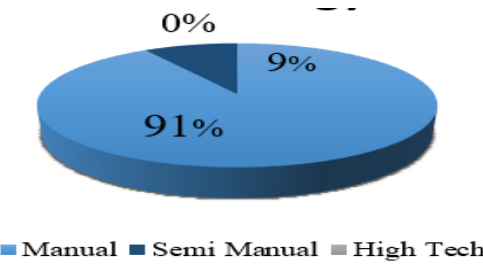

Figure 11. Technology Women's Home-Based Workers

Capital is often made a scapegoat as the most important element for doing an effort (Figure 8 and 9). Home-based workers virtually imaged that developed in the two villages have a capital of fewer than 5 million dollars, and only approximately $34 \%$ of the capital sourced from its capital. While $65 \%$, part of capital sourced from the loan. Likewise, most business licenses don't have. $91 \%$ of home-based workers further still use the manual, only about $9 \%$ who use semi-manual, and there has not been at all the use of high technology. Production technology is highly related to the workforce. Women's home-based workers many still use manual ability and skill the human labor is the mainstay of its business. While businesses have been using manual spring technology, they have been using the most appropriate technology to improve the quality and quantity of the products.

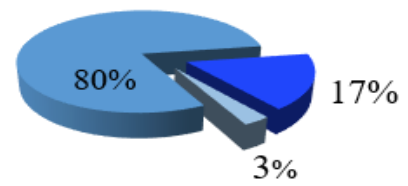

[ 3-5 People 6-10 People " 1-2 People

Figure 12. The amount/Number of Labor Women's Home-Based Workers

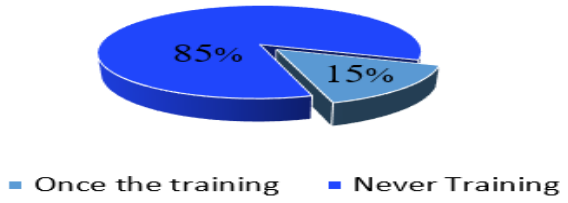

Figure 13. Training Experience Women's HomeBased Workers

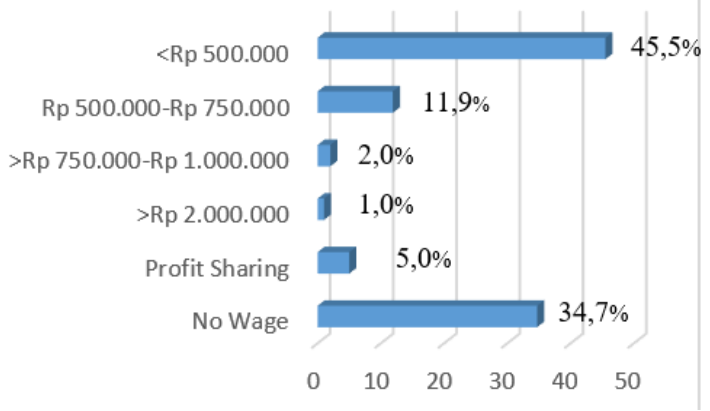

Figure 14. Salary Women's Home-Based Workers

As much as $80 \%$ of home-based workers have labor (including the owner), 1-2 people. While the effort has a workforce of 3-5 people reached 16.8 percent, and still very small or only about 3 percent of businesses have workforce 6-10 people. The limited number of labor, correlated with the sustainable effort because of high dependence on limited manpower. Although the number of labor each home workers haven't been able to absorb the workforce in great numbers, due to the number of home-based workers many business units, then labor was absorbed relatively much. Of the new business unit 101, $15 \%$ who have experience training.

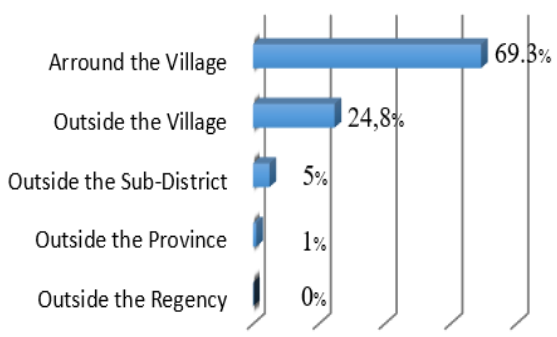

Figure 15. The area of marketing Women's Home-Based Workers

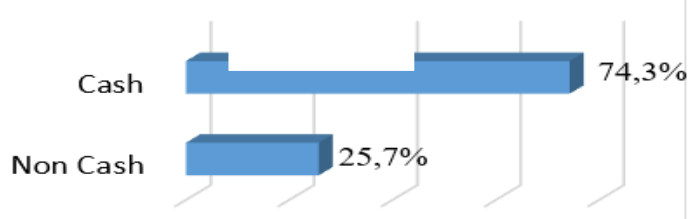

Figure 16. Payment Method Women's HomeBased Workers 
Cash

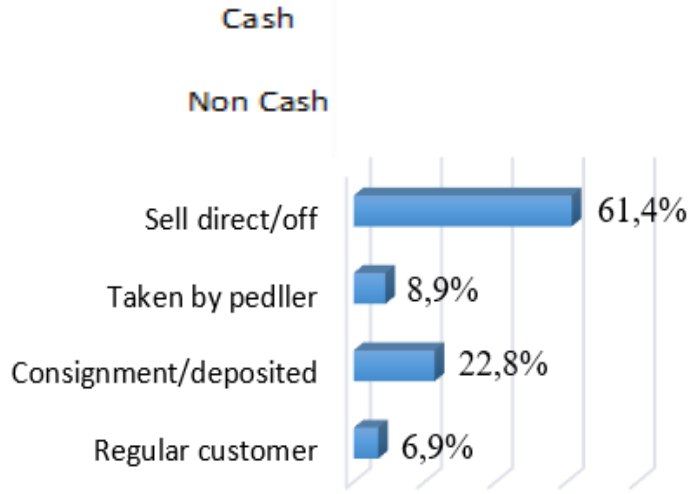

Figure 17. Sales Women's Home-Based Workers

Figure 15 describes the uncertainty of marketing still experienced by more than $90 \%$ of women home-based workers. An indication of the uncertainty is also supported by data on the area of marketing that make sales around the village. The limited sales area allows the occurrence of ' saturation ' demand at certain times. This will be promoted to a large number of production/limited. Different when you have extensive marketing, allows to enlarge the number of production. Perpetrators who commit cash payments reaching $74.3 \%$. The magnitude of the cash payment can be an indication of the limited capital turnover of home-based workers.

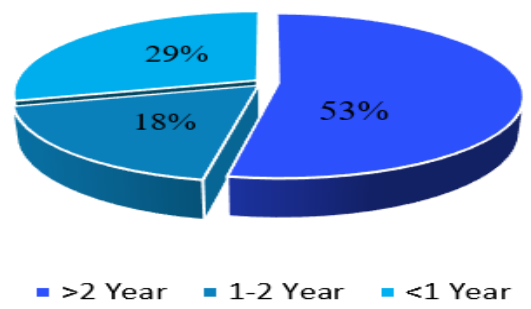

Figure 18. Old Business Women's Home-Based Workers

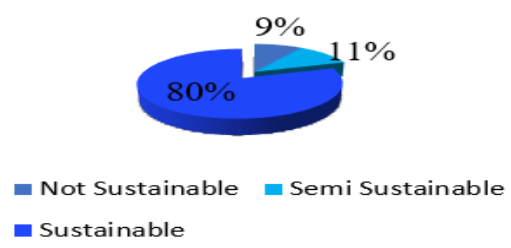

Figure 19. Pattern Production Women's HomeBased Workers

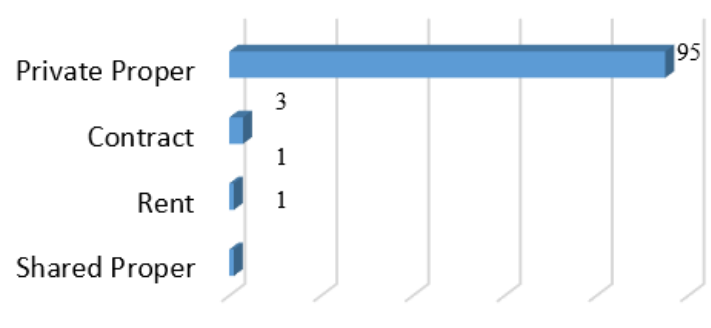

Figure 20. Sustainability Efforts. Women's HomeBased Workers

Various types of home industry venture above pursued seriously and worked on an ongoing basis. This can be scrutiny from 1) most attempts have been made over 2 years, reached $53 \%, 2$ ) as much as $80 \%$ have done production continuously, 3) as much as $95 \%$ has had its place of business.

\subsection{Home Industry Policy: Affirmative Decent Work Policy}

Poverty and Increasing Women's Economic Productivity (PPEP) are the focus of the government's affirmative strategy, in this case Kementerian Pemberdayaan Perempuan dan Perlindungan Anak (Ministry of Women's Empowerment and Child Protection), in improving the quality of life and fulfilling women's economic rights [25]. Gender inequality in the economic sector has the potential to cause public distrust (trust) of the development results. The failure of the strategy to develop a model of economic empowerment for women's groups, because the local government development strategy for women workers is carried out sporadically and is usually incidental, not based on a community learning model so that the impact of the business development of women economic workers is difficult to monitor and evaluate. Contradictory facts show that many economic workers at the micro and super levels Micro is carried out by women's groups, and is usually carried out at home, while on the other hand, the fact is that the growth of types of businesses managed by women is increasingly rapid, even though the contribution to GRDP is low, the productivity of workers is lagging behind, but home work done by women is able to play a strategic role in increasing the dynamics of the village economy, especially in sucking up the overflow of labor [8]; [27]; [28] ;[29].

The government through its main leading sector, namely Kementrian Pemberdayaan Perempuan dan Perlindungan Anak RI (KPPPA RI) or the Ministry of Women's Empowerment and 
Child Protection of the Republic of Indonesia (KPPPA RI), responded by issuing a package of policies to increase women's economic productivity (WEP) in 2014, to support women's empowerment activities in the economic sector. Furthermore, through a Ministerial Regulation of PPPA Nomor 2 Tahun 2016, a mass home industry (IR) development program was implemented to improve family welfare through empowering women. The focus of the development of the home industry is directed at ending the economic gap between men and women (gender equality) [25].

Home Industry Policy, is a policy affirmative option that emphasizes locality, whether institutional, community, environment, culture, there is partiality and empowerment which is understood as a process of transforming social, economic relations and protecting women's businesses. The policy is characterized by transformative and transactive planning, bottom up, community empowerment and participative making this policy an innovative model that is quite effective, integrated, sustainable, specific and operational, based on learning that is expected to answer the needs of women home industry players. [8]; [27]; [28]; [29]; [30]. Cottage Industry conception, in version of KPPPA RI [25] is: a production system, which means that a product is produced through the process of forming added value from certain raw materials, which is carried out in an individual home and not in a special location (factory). The production process utilizes infrastructure, facilities and other production equipment owned by individuals / joint business groups / cooperatives. Generally the products from the Home Industry are hand made, are unique in different ways, and are often associated with local wisdom and targeted technology.

This affirmative policy strategy is aimed at: 1) reducing unemployment, through expanding entrepreneurship in micro enterprises; 2) Responding to the moratorium on Indonesian migrant workers, most of whom are women workers; 3) The need for effective and targeted public policies for the coordination of Home Industry Development, of which $70-75 \%$ are female workers and women's economic rights [25]. Home industry policies with target directions: 1) Increase family income through productive activities carried out at home by women homeworkers with growing support from their husbands and other family members; 2) Opening alternative business opportunities; 3) Developing creative industries through women's empowerment activities in order to strengthen the home industry network [25].
The classification used in looking at women's businesses uses the following classifications: First: Home Industry (HI) Beginners, generally the production is not continuous, the sales system is loose, the capital is relatively small, the production process is still simple done manually, the number of workers is 1-2 people including the owner. Second, HI (Home Industry) Developing, generally semicontinuous production with a loose sale system, the capital is still relatively small according to its own capacity and has started borrowing funds from nonformal MFIs, which is around 5- $<25$ million rupiah, the production process already uses technology / semi manual, the number of workers is around 3-5 people including the owner. Third, advanced HI (Home Industry), generally production is continuous, the level of business sustainability is high because it is able to manage the business well, capital ranges from 25-50 million, the production process uses high / clean technology with a workforce of around 6-10 people including the owner [25]. Important dimensions in the home industry implementation strategy are as follows: Capital, limited marketing, Policy. Coordination, Assistance. Using the above classification and model, the picture of changing conditions for women homeworkers is as follows:

Table 1. Changes in Women Homeworkers in Sample Villages

\begin{tabular}{llcccc}
\hline \multirow{2}{*}{ No } & Categories & \multicolumn{2}{c}{$\mathbf{2 0 1 9}$} & \multicolumn{2}{c}{$\mathbf{2 0 2 0}$} \\
\cline { 3 - 6 } & & Amount & \% & Amount & \% \\
\hline 1 & HI 1 (beginner) & 2 & 1,98 & 0 & 0.00 \\
\hline 2 & $\begin{array}{l}\text { HI 2 } \\
\text { (developing) }\end{array}$ & 93 & 92.08 & 79 & 78.22 \\
\hline 3 & HI 3 (advanced) & 6 & 5.94 & 22 & 21.78 \\
\hline & Amount & 101 & 100 & 101 & 100 \\
\hline
\end{tabular}


Table 2. Income Per Week for Women Homeworkers

\begin{tabular}{|c|c|c|c|c|c|}
\hline \multirow{2}{*}{$\begin{array}{l}\mathbf{N} \\
\mathbf{o}\end{array}$} & \multirow[b]{2}{*}{ Income } & \multicolumn{2}{|c|}{2019} & \multicolumn{2}{|c|}{2020} \\
\hline & & Amount & $\%$ & $\begin{array}{l}\text { Amou } \\
\text { nt }\end{array}$ & $\%$ \\
\hline 1 & $<500.000$ & 17 & 16.83 & 4 & 3.96 \\
\hline 2 & $\begin{array}{l}500.000- \\
1.000 .000\end{array}$ & 30 & 29.70 & 33 & $\begin{array}{l}32.6 \\
7\end{array}$ \\
\hline 3 & $\begin{array}{l}1.000 .000- \\
3.000 .000\end{array}$ & 43 & 42.57 & 48 & $\begin{array}{l}47.5 \\
2\end{array}$ \\
\hline 4 & $\begin{array}{l}3.000 .000- \\
5.000 .000\end{array}$ & 6 & 5.94 & 5 & 4.95 \\
\hline 5 & $\begin{array}{l}5.000 .000- \\
10.000 .000\end{array}$ & 4 & 3.96 & 8 & 7.92 \\
\hline 6 & $>10.000 .000$ & 1 & 0.99 & 3 & 2.97 \\
\hline \multicolumn{2}{|c|}{ Amount } & 101 & 100 & 101 & 100 \\
\hline
\end{tabular}

Based on the table above, we can see that there are no actors in the category of $\mathrm{HI} 1$ or Beginners in 2020. The increase occurred in the category of $\mathrm{HI}$ 3 , which originally numbered $6 \mathrm{HI}$ perpetrators and increased to $22 \mathrm{HI}$ actors. The increase indicates an increase in income, the amount of capital, and the use of technology. Likewise with income, for approximately one year there was an increase in income from home industry players, namely as many as 48 people $(47.52 \%)$ of home industry players currently have an income of $1,000,000$ to $3,000,000$ per week. The existence of a home industry forum, assets in the form of kiosks demonstrating the feasibility of women homeworkers. The design of the home industry model has made the work of women from home deserve.

This study describes the working conditions of women whose activities are carried out at home independently which makes an important contribution to the economy of the family, society and the country. However, they are working in substandard conditions and that requires efforts by various stakeholders, especially the government. As women homeworkers work to support their livelihoods and the well-being of their families, it is important to recognize them as workers and strive towards addressing the decent work deficits faced by homeworkers. In promoting decent work for homeworkers, actions must be taken by the relevant stakeholders to bring about positive change at different levels including at the policy level. As the majority of homeworkers are women, promotion of decent work for homeworkers is an important area of work in improving the welfare of women in Indonesia. Improving the working conditions of homeworkers can have a positive impact as Indonesia strives towards poverty alleviation and sustainability of development.

\section{CONCULSION}

In order to address the decent work deficit problem, the main recommendations for promoting decent work for women home-based self-employed workers are as follows:

1. There is a need for special regulations as a form of acknowledgment of the existence of homeworkers through laws on a national scale and regional regulations on a local scalea. Recognize homeworkers as workers through legislation on a national scale, or through local regulations

2. Awareness raising, training, formation and group management as a medium for empowering homeworkers to address decent work deficits through

3. Social protection for homeworkers needs to be extended

4. An environmental atmosphere that ensures gender equality needs to be created through outreach activities and campaigns on gender equality and non-discrimination among the general public, policy makers, companies and employers' associations, trade unions, and 60 related organizations.

5. The data relating to homeworkers need to be properly collected and documented.

\section{ACKNOWLEDGMENTS}

1. Institute for Research and Community Service, University of Lampung through the Institutional Grant Program Scheme;

2. Government of South Lampung Regency \& Government Lampung Province

\section{REFERENCES}

[1] Domańska,A, et all 2019 Sustainable Development versus Gender Gap - Do Women Matter? Journal of Problemy Ekorozwoju (Problems of Sustainable Development) Vol 14 (2) pp 129-142

[2] Hłobił, A, 2010 Ecological Education for Sustainable Development - Theory and Practise Journal Problema EkorozwojuProblems of Sustainable Development Vol 5 no 2 pp 87-94

[3] ILO 2019 Decent Work Country Programme (DWCP) Indonesia (https:// www.ilo.org/ 
jakarta/

indonesia/WCMS_507515/lang--

country/

en/index.htm)

[4] Olga Novikova, O, et all 2019 Mechanism of Strengthening Social and Labor Potential of Sustainable Development Journal Problema Ekorozwoju-Problems of Sustainable Development Vol. 14, no 1, pp 63-72

[5] Allen, E 2013 Labour and social trends in Indonesia 2013: Reinforcing the role of decent work in equitable growth (ILO, Jakarta).

[6] ILO Geneva 2001 Report of the DirectorGeneral: Reducing the decent work deficit a global challenge

[7] [7] Raelin J A, 1997 A Model of WorkBased Learning Journal Organization Science Vol. 8, No. 6, pp 563-578

[8] Tresiana, N and Duadji,N, 2019 Mewujudkan Gender Equality Melalui Pengembangan Industri Rumahan. Jurnal Musawa 18 (2), No. 2, pp 119-131

[9] BPS-Statistic Indonesia, 2016, National Labor Force Survey (SAKERNAS), Jakarta

[10] Chen, M 2014 Informal Economy Monitoring Study Sector Report: HomeBased Workers, WIEGO Secretariat: Cambridge, USA

[11] Carrón P, 2008 Women Workers, Industrialization, Global Supply Chains and Corporate Codes of Conduct Journal of Business Ethics Vol 83 pp 5-17

[12] Rai S M et all, 2019 SDG 8: Decent work and economic growth - A gendered analysis Journal World Development. Vol 113. p 368-380

[13] Chen M A and Sinha S, 2016 Home-based workers and cities, Journal Environ. Urban. pp 1-16

[14] Chen M A and Tate J 2000 Globalization and Home-Based Workers Journal Feminist Economics 6(3) pp123-142

[15] Mehrotra S and Biggeri, M (eds) 2007 Asian informal workers: Global risks, local protections: Routledge, London dan AS.

[16] N. Haspels and Matsuura, A 2015 Homebased workers: Decent work and social protection through organization and empowerment. Experiences, good practices and lessons from home-based workers and their organizations (Jakarta, ILO).

[17] Kim,E.M, 2017 Gender and the Sustainable Development Goals. Global Social Policy 17 (2) pp 239-244.

[18] Doane, D.L, 2017 Beyond Safety Nets: Linking Social Protection to Technology/Industrial Policies for Informal Women Workers Journal Gender, Technology and Development Volume 8 (3) pp 335-358

[19] Kansanga, M,M, 2019 A feminist political ecology of agricultural mechanization and evolving gendered on-farm labor dynamics in northern Ghana Journal Gender, Technology and Development Volume 23 (3) pp 207-233

[20] Head B. W., 2014 Public Administration and The Promise of Evidence-Based Policy: Experience in and Beyond Australia Journal Asia Pacific Journal of Public Administration Vol 36 (1) pp 48-59

[21] Hanrahan, F 2017 Menggunakan Bukti untuk Membuat Kebijakan Sosial: Pelajaran dari Australia Sejak 2007 hingga 2017 Working Paper 21 ( Kerjasama Knowledge Sector Initiative, Australian Government, dan Kementrian PPN/Bappenas RI). Indonesia: Knowledge Sector Initiative. https://www.ksiindonesia.org/old/in/news/detail/menggunak an-bukti-untuk-membuat-kebijakan-sosialpelajaran-dari-australia-sejak-2007-hingga2017

[22] Hall P A, 1993 Policy Paradigms, Social Learning, and the State: The Case of Economic Policymaking in Britain Journal Comparative Politics Vol. 25 (3) pp. 275296

[23] Pathania, S.K, 2017 Sustainable Development Goal: Gender Equality for Womens Empowerment and Human Right International Journal of Research Granthaalayah 5(4) pp 72-82

[24] Netting, F. Ellen N,F, et all 1993 Social Work Macro Practice. New York: Longman

[25] Kementrian Pemberdayaan Perempuan dan Perlindungan Anak Republik Indonesia 2016 Petunjuk Pelaksanaan Industri Rumahan, Jakarta Indonesia

[26] Badan Pusat Statistik Kabupaten Lampung Selatan 2016B Kabupaten Lampung 
Selatan dalam Angka. Kalianda: BPS Kabupaten Lampung Selatan Indonesia

[27] Tresiana, N dan Duadji N,2019 Gender Equality dan Inovasi kebijakan Publik, Graha Ilmu: Yogyakarta

[28] Tresiana, N dan Duadji N, 2020 Model Koproduksi Pengembangan Program Padat Karya Tunai Desa dalam Menangkal Dampak Covid19 yang mendukung Gender Equality di Kabupaten Lampung Selatan Laporan Kemajuan PenelitianTerapan unggulan Perguruan Tinggi Tahun kedua, Jakarta: Kementrian Riset dan Teknologi/Badan Riset dan Inovasi Nasional, Deputi Bidang Penguatan Riset dan Pengembangan Republik Indonesia

[29] Tresiana, N dan Duadji N, 2019 Model Klaster dalam Pengembangan Industri Rumahan Guna Mewujudkan Kesetaraan gender di Kabupaten Lampung Selatan Laporan Kemajuan PenelitianTerapan unggulan Perguruan Tinggi Tahun Pertama Jakarta: Kementrian Riset dan Teknologi/Badan Riset dan Inovasi Nasional, Deputi Bidang Penguatan Riset dan Pengembangan Republik Indonesia LPPM Unila. Bandar Lampung (Tidak Dipublikasikan)
[30] Deranty J P and MacMillan C 2012 The ILO's decent work initiative: Suggestions for an extension of the notion of decent work Journal of Social Philosophy Vol 43 (4) pp 386-. 